\title{
Employee insolvency priorities and employment protection in France, Germany and the United Kingdom
}

\author{
FEDERICO M. MUCCIARELLi*
}

When an employer becomes insolvent, employees' claims for unpaid wages and contributions may be protected through either statutory priorities, or social security schemes, or a combination of both strategies. This paper compares the interplay of employee statutory priorities, if existing, and social security schemes in France, Germany and the United Kingdom. While France protects employees through both a statutory priority and a social security scheme, Germany and the U.K. have progressively reduced employment protection over the last forty years. It will be shown that the theories of varieties of capitalism and of legal origins cannot fully describe and explain the development of employment protection strategies in most of these countries. The evolution of German and U.K.'s regimes, in particular, are better explained as a sign of profound cultural shifts regarding the position of labour within firms and vis-à-vis other stakeholders. Finally, this paper also takes a stance with the concept of functional equivalence' in comparative law, by showing that a cumulative application of employee priorities and insurance schemes is not necessarily redundant.

* SOAS, University of London, School of Finance and Management, Thornhaugh Street, Russell Square, London WC1H OXG, England,fm11@soas.ac.uk - University of Modena and Reggio Emilia, Department of Economics and CEFIN, viale Berengario 51, 41121 Modena, Italy, federicomaria.mucciarelli@unimore.it.

Preliminary versions of this paper were presented at the SLSA annual conference, University of Warwick, 31 March - 2 April 2015 and the WINIR annual conference in Rio de Janeiro, 10 - 13 September 2015. I would like to thank Richard Alexander, Davide Casale, Carsten Gerner-Beuerle, Nicholas Foster, Mathias Siems and Nikhilesh Sinha for their comments and suggestions. All errors and opinions are mine. 
This is the version of the article accepted for publication in the Journal of Law and Society that will be published by Wiley: http://onlinelibrary.wiley.com/journal/10.1111/(ISSN)1467-6478/issues

Accepted version downloaded from SOAS Research Online: http://eprints.soas.ac.uk/23221/

\section{INTRODUCTION}

A standard principle of all insolvency regimes is that secured creditors take priority over other creditors and unsecured creditors are treated equally. In several jurisdictions, however, specific categories of unsecured claims, notably employees' claims for unpaid wages and contributions, are entitled to preferential treatment. Several comparative works have classified employee priorities around the world ${ }^{1}$ and have addressed the complex issue of creditor statutory priorities ${ }^{2}$, but only few of them have assessed the institutional environment in which these priorities are embedded. ${ }^{3}$ Employees, indeed, may also be protected through social security schemes established for compensating due wages and contributions that the insolvent employer has not paid. Thus, to understand how employees are protected against this risk, it is necessary analysing the interplay between employee priorities (if existing) and social security schemes across different jurisdictions, looking for common patterns or divergences. A common explanation for diverging combinations of institutional strategies across jurisdictions is the idea that such divergences are closely linked with specific national production regimes or with historical legal background. Within this conceptual framework, the theory of 'varieties of capitalisms' and the 'legal origins hypothesis' have gained a particular relevance: the former classifies all countries along the distinction between 'liberal' and 'coordinated market economies', while the latter argues that capital market developments depend on whether the legal origin of each jurisdiction is rooted in common law or civil law. ${ }^{4}$

This paper will critically compare the interplay between employee priorities (if existing) and social security schemes in three Member States of the European Union: France, Germany and the United Kingdom 5 . These jurisdictions are representative of different 'varieties of capitalism' and 'legal origins': while the United Kingdom is a model of 'liberal market economies', and England is the birthplace of all common law jurisdictions, Germany and France are typical

\footnotetext{
${ }^{1} \mathrm{~W}$. Huaiyu, 'An international comparison of insolvency laws' (2006) OECD $5^{\text {th }}$ forum on Asian Insolvency Reform, 27-28 April 2006, <http://www.oecd.org/china/38182541.pdf> (comparing insolvency regimes in 42 countries); G. W. Johnson, 'Insolvency and social protection: employee entitlements in the event of employer insolvency' (2006) OECD $5^{\text {th }}$ Forum on Asian Insolvency Reform, $<$ http://www.oecd.org/daf/ca/corporategovernanceprinciples/38184691.pdf $>$; J. Sarra, 'Recognizing workers; economic contributions: the treatment of employee and pension claims during company insolvency: a comparative study of 62 jurisdictions' (2008) < http://iiiglobal.org/component/jdownloads/finish/572/5379.html > (who compared 62 jurisdictions); P. M. Secunda, 'An Analysis Of The Treatment Of Employee Pension And Wage Claims In Insolvency And Under Guarantee Schemes In OECD Countries: Comparative Law Lessons For Detroit And The United States' (2014) 41 Fordham Urban Law Journal, 867.

${ }^{2}$ See the works of J. M. Garrido: 'The distributional question in insolvency: comparative aspects' (1995) 4 International Insolvency Review, 25; Preferenza e proporzionalità nella tutela del credito (1998); 'No two snowflakes the same: The distributional question in international bankruptcies' (2011) 46 Texas International Law Journal 459. See also: J. L. Westbrook, 'Universal Priorities' (1998) 33 Texas International Law Journal 27; J. A. Pottow, 'Greed and pride in international bankruptcy: the problems of and proposed solutions to local interests' (2006) 10 Michigan Law Rev. 1899; A. Piekenbrock, 'Insolvenzprivilegien im deutschen, ausländischen und europäischen Recht' (2009) 122 Zeitschrift für Zivilprozessrecht 63; P. Omar, 'The challenge of diverse priority rules in European insolvency laws' (2011) Eurofenix, Autumn, 32; J. L. Westbrook, C. D. Booth, C. G. Paulus and H. Rajak, A Global View of Business Insolvency Systems (2010) $184-195$.

${ }^{3}$ See the studies of Johnson and Secunda, op. cit., n. 1.

${ }^{4}$ See the seminal paper of R. La Porta, F. Lopez-de-Silanes, A. Shleifer and R. W. Vishny, 'Legal determinants of external finance' (1997) 52 The Journal of Finance 1131.

${ }^{5}$ For simplicity, this study will refer to English law and to the English insolvency regime, codified by the Insolvency Act 1986, which applies in England, Wales and, with few exceptions, Scotland. In Northern Ireland, however, insolvencies are regulated by the The Insolvency (Northern Ireland) Order 1989, which entails rules that are in line with those of the Insolvency Act 1986. Therefore, all arguments discussed in this study are to be extended to all countries of the United Kingdom.
} 
'coordinated market economies' and models for civil law systems around the world ${ }^{6}$ Comparing the strategies of these three countries for protecting employees from the risk that an insolvent employer does not pay due wages, therefore, casts light on the use of the theory of 'varieties of capitalisms' and the 'legal origins' hypothesis in comparative company and insolvency law. Interestingly, this perspective also challenges the separation between private law, dealing only with inter-private conflicts, as opposed to public law, dealing with top-down regulations and redistribution mechanisms. Although creditors' priorities are private law instruments, they also serve a social function, which could also be fulfilled by typical public law strategies, such as social security schemes. This question may be alternatively formulated by asking whether employee priorities and social security schemes are functional equivalents.

The paper is structured as follows. The next section describes the 'varieties of capitalism' theory and the legal origin hypothesis. The third section addresses the main goals of insolvency proceedings and illustrates the reasons why many insolvency regimes deviate from the principle of equal treatment of creditors. The fourth section compares French, German and English regimes; it will be shown that in the last 40 years England and Germany have developed in the same direction - namely reducing or repealing employee priorities - while the French regime of employment protection has remained unaltered. An historical analysis, therefore, reveals a complex scenario, that does not fully reflect the fracture between 'liberal' and 'coordinated' market economies, and between common law and civil law countries. The last section tries to make sense of this complex scenario; first of all, it will be shown that the tendency to replace employee priorities through social security schemes reveals a conceptual and cultural shift as to the position of labour in the business; finally, it will be argued that that employee priorities and social security mechanisms are not mere functional equivalents, with the consequence that their cumulative application is not always redundant.

\section{SETTING THE SCENE: VARIETIES OF CAPITALISM, LEGAL ORIGINS AND CREDITOR PROTECTION}

Two theories on the interplay of different institutional settings in different jurisdictions have gained prominence in the most recent scholarly researches on comparative company and insolvency law and have triggered a quite intense and still on-going debate: the 'varieties of capitalism' approach, and the 'legal origin' hypothesis.

The 'varieties of capitalism' approach, rather than a single theory, is a bundle of theories having some common elements. According to its first conceptualization, national political economies can be segmented into five institutional spheres: industrial relations, vocational training, corporate governance, inter-firm relations and worker- management relations. ${ }^{7}$ National equilibriums among these spheres are clustered into two ideal-types of economies: 'liberal market economies' and 'coordinated market economies'. In the former, firms and other social actors coordinate their relations mostly by way of competitive market arrangements and market transactions. By contrast, in coordinated market economies, firms and other social actors also rely upon non-market relationships and top-down regulation.

The interplay and the combinations between different institutional settings are commonly characterised by reference to the concept of 'complementarity' between institutions. The starting point is that in each national economy, different institutional settings normally provide coherent

\footnotetext{
${ }^{6}$ P. A. Hall and D. Soskice, 'Introduction to varieties of capitalism', in Varieties of Capitalism: The Institutional Foundations of Comparative Advantage, eds. Hall and Soskice (2001).

${ }^{7}$ P. A. Hall and D. Soskice, op. cit., n. 6.
} 
incentives, reinforcing each other's efficiency and returns. ${ }^{8}$ Institutions are considered complementary to each other when the presence of one institution reinforces the efficiency and the returns of other institutions ('complementarity as reinforcement'). In Germany, for example, companies rely on long-term investments and require employers to enter into firm-specific engagement, which corresponds to higher job stability and employment protection. ${ }^{10} \mathrm{~A}$ consequence may be that different institutional settings, in order to work efficiently, should be coherent and should aim at attaining the same goals, while contradictory incentives and noncoherent institutions risk being inefficient. ${ }^{11}$

This approach has triggered an intense debate. Indeed, within the same country, different institutional settings could be combined in several, sometimes apparently inconsistent, manners. Therefore, other scholars have argued that the concept of institutional complementarity should also explain institutional combinations and developments in the absence of a system designer that exclusively pursues abstract concepts of efficiency. ${ }^{12}$ Institutions, in particular, could 'mutually compensate for each other's deficiencies', instead of pursuing identical goals. ${ }^{13}$ This is the case when the tendency of an institution offsets the outcomes of other institutions or other social mechanisms ('complementarity as compensation').

The legal origin hypothesis, by contrast, is a coherent theory, according to which financial development and investor protection largely depend on whether a country's legal origin is common law or civil law. ${ }^{14}$ The first papers that tested the legal origin hypothesis argued that common law countries (England and all derivative legal systems, including the U.S.) are better equipped for protecting creditors and outside investors, and that this origin explains their greater financial development in comparison to 'civil law' systems, in particular French-derived jurisdictions. ${ }^{15}$ According to this view, the main reason of this difference is that common law' countries have a higher judicial flexibility and that they better protect property rights. In one of their latest contributions, La Porta et al. expanded the concept of legal origin, by adopting a broad conception of legal origin as a 'style of social control of economic life', according to which 'common law stands for the strategy of social control that seeks to support private markets outcomes, whereas civil law seeks to replace such outcomes with state-desired allocations'. ${ }^{16}$ Interestingly, such expanded concept of legal origin perfectly fits into the distinction between liberal and coordinated market economies. Along this line of thought, it has been argued that a correlation exists between variety of capitalism and legal origin, since most liberal market economies have a common law origin, whereas most civil law jurisdictions are coordinated market economies. ${ }^{17}$ The legal origins hypothesis was also applied to classify labour relations. ${ }^{18}$

\footnotetext{
${ }^{8}$ Hall and Soskice, op. cit., n. 6, pp. 19 - 22; P. A. Hall and D. W. Gingerich, Varieties of capitalism and institutional complementarities in the political economy: an empirical analysis' (2009) 39 British Journal of Political Studies, 449.

${ }^{9}$ Hall and Soskice, op. cit., n. 6, p. 7; B. Amable, The Diversity of Modern Capitalism (2003).

${ }^{10}$ Hall and Soskice, op. cit., n. 6, p. 6.

${ }^{11}$ Hall and Gingerich, op. cit., n. 8.

12 W. Streeck, 'Requirements for a useful concept of complementarity' (2005) 3 Socio-Economic Review, at 363.

${ }^{13}$ C. Crouch, Capitalist Diversity and Change (2005) 50 and 'Welfare state regimes and industrial relations systems: the questionable role of path dependency theory', in Comparing welfare capitalism, eds. Ebbinghaus and Manow (2014) 105.

14 This classification is just one of the possible classifications of legal systems developed by comparative legal scholars; for an overview see: M. Siems, Comparative law (2014) $74-80$.

${ }^{15}$ See in particular: La Porta, Lopez-de-Silanes, Shleifer and Vishny, op. cit., n. 4, p. 1131; La Porta, Lopez-deSilanes, Shleifer and Vishny, 'Law and finance' (1998) 106 Journal for Political Economy 1113.

${ }^{16}$ La Porta, Lopez-de-Silanes and Shleifer, 'The economic consequences of legal origins' (2008) 46 Journal of Economic Literature 285, at 286.

${ }^{17}$ K. Pistor, 'Legal Ground Rules in Coordinated and Liberal Market Economies', in Corporate Governance in Context: Corporations, States, and Markets in Europe, Japan, and the US, eds. Hopt, Wymeersch, Kanda, Baum (2005) 249.
} 
This is the version of the article accepted for publication in the Journal of Law and Society that will be published by Wiley: http://onlinelibrary.wiley.com/journal/10.1111/(ISSN)1467-6478/issues

Accepted version downloaded from SOAS Research Online: http://eprints.soas.ac.uk/23221/

Botero et al., in particular, selected three main areas of states' regulatory intervention (employment laws, collective relation rules and social security) and coded the rules included in these areas. The conclusion of this study was that common law countries protect employees less than civil law countries, and that a higher protection is associated with certain inefficiencies, such as higher unemployment and larger unofficial economy. ${ }^{19}$ Their work, however, does not include employment protection through insolvency priorities.

Several scholars, however, have raised methodological objections to the legal origin hypothesis. One of the main criticisms is that in La Porta et al. study, variables representing laws and law systems are time-invariant and the analysis is simply cross-sectional. ${ }^{20}$ Therefore, this approach does not take into account historical developments and cannot exclude reverse-causality. ${ }^{21}$ Furthermore, in the legal origin model the legal dimension is an entirely exogenous phenomenon, while in reality the law is, at least in part, endogenous to economic development and political and social dynamics. ${ }^{22}$ Some authors also maintain that the legal origin approach suffers from two other substantial flaws under a comparative viewpoint. First of all, legal families are depicted in an oversimplified fashion, which is biased in favour of common law countries. ${ }^{23}$ Secondly, the descriptions of the institutional settings within each country, and within each legal family, do not take into account that in different countries functional substitutes could be in place aiming at attaining similar goals. ${ }^{24}$ With the aim of addressing these problems, other scholars have recently constructed a new comparative scale considering a wider range of variables related to creditor protection mechanisms (hereinafter: the 'CBR Index'). ${ }^{25}$ The CBR Index, differently from the comparative scale developed by La Porta et al., in order to capture a more realistic picture of creditor protection strategies also considers other variables, including mechanisms for protecting unsecured creditors. ${ }^{26}$

18 J. C. Botero, S. Djankov, R. La Porta, F. Lopez-de-Silanes and A. Shleifer, 'The regulation of labor' (2004) The Quarterly Journal of Economics, 1339. For an overview see: Z. Adams and S. Deakin, 'Quantitative labour law', in New frontiers in empirical labour law research eds. Ludlow and Blackham (2015) $31-50$.

${ }^{19}$ Botero et al. op. cit., n. 18, p. 1378.

${ }^{20}$ J. Armour, S. Deakin, V. Mollica and M. Siems, 'Law and financial development: what we are learning from time-series evidence?’ (2009) Brigham Young University Law Review 1435.

${ }^{21}$ See, for instance: J. C. Coffe Jr, 'The rise of dispersed ownership: the roles of law and the State in the separation of ownership and control' (2001) 111 Yale Law Journal 1; Armour, Deakin, Mollica and Siems, 'How do legal rules evolve? Evidence from a cross-country comparison of shareholder, creditor, and worker protection' (2009) 59 American Journal of Comparative Law 579, at 586.

22Armour, Deakin, Mollica and Siems op. cit., n. 20 p. 1450; J. Buchanan, D. H. Chai and S. Deakin, 'Empirical analysis of legal institutions and institutional change: multiple methods approaches and theory application to corporate governance research' (2014) 10 Journal of Institutional Economics 1, at 12.

${ }^{23}$ P. Lele and M. Siems, 'Shareholder protection: a leximetric approach' (2007) 7 Journal of Corporate Law Studies 17.

${ }^{24}$ B. Ahlering and S. Deakin, 'Labor regulation, corporate governance and legal origin: a case of institutional complementarity?' (2007) 41 Law and Society Review 865; Deakin, Lele and Siems, 'The evolution of labour law: calibrating and comparing regulatory regimes' (2007) 146 International Labour Review, 133 at 136 - 141.

${ }^{25}$ Armour, Lele, Mollica and Siems, 'CBR Creditor Protection Index for the UK, the US, Germany, France, and India' (2006) Centre for Business Research, University of Cambridge. This index has been recently extended to cover 30 countries for a period stretching between 1990 and 2013: see the whole updated dataset $<$ www.repository.cam.ac.uk/handle/1810/256566>.

${ }^{26}$ See: S. Deakin and P. Sarkat, 'Does creditor protection matter? Legal and financial development in four OECD countries, 1970 / 2005', working paper on <www.ssrn.com/abstract=2613879> and Deakin, Mollica and Sarkar, 'Varieties of creditor protection: insolvency law reform and credit expansion in developed market economies' (2016) 14 Socio-Economic Review 1. The same authors have also coded labour protection in France, Germany, the U.K., India and the U.S. (<http://www.cbr.cam.ac.uk/research/research-projects/completed-projects/law-financedevelopment/>). Additionally, see also Armour, Deakin and Siems, CBR Leximetric Datasets. <http://dx.doi.org/10.17863/CAM.506>, coding labour law of 117 countries. 
Despite this significant difference, the index developed by La Porta et al. and the CBR Index share a similar approach regarding the variable measuring creditor protection, since a country receives a score of 1 when secured lenders are prioritised over any other creditors and when they can enforce their rights outside the procedure, whereas countries where statutory priorities are in place, or where a statutory stay applies to secured creditors, receive a lower score. ${ }^{27}$ In other words, these specific variables only measure the priority system and the protection of secured creditors, not the protection of any kinds of creditors, and seem to move from the implicit assumption that secured creditors' absolute priority is per se a desirable policy goal. ${ }^{28}$ In this regard, the most common argument supporting secured creditors' protection is that it avoids debtors' moral hazard, reduces the overall cost of credit and increases the willingness to lend. ${ }^{29}$ It is worth stressing, however, that the rationale for secured creditors' absolute priority is debated and still puzzling. Several scholars, indeed, argue that secured credit absolute priority only redistributes value from non-sophisticated and involuntary creditors to sophisticated creditors $\mathrm{s}^{30}$, and that efficiency gains are not, or not always, ascertainable. ${ }^{31}$

It is now clear why, and to what extent, the 'varieties of capitalism' approach and the 'legal origin' hypothesis are significant for comparative legal researches and for understanding employee priorities. These theories, indeed, make possible a comparison of the interplay among complex and interdependent institutional settings pursuing similar goals. Regarding employee priorities, which alter expost free-market bargains between a debtor and its creditors, both theories would predict that in 'liberal market economies' (and common law countries) no employee priorities should exist, and that 'coordinated market economies' (and civil law countries) should be more open to statutory priorities shaping the balance among stakeholders.

${ }^{27}$ See: La Porta, Lopez-de-Silanes, Shleifer and Vishny, op. cit., n. 15 p. 1135; Armour, Lele, Mollica and Siems, 'CBR Creditor Protection Index for the UK, the US, Germany, France, and India' (2006) Centre for Business Research, University of Cambridge.

${ }^{28}$ It is necessary remembering that a difference exists between the La Porta index and the CBR Index, as we have seen above: while the former is exclusively based upon this variable measuring secured creditor protection, the latter also measures, through other variables, the level of protection of unsecured creditors and is, consequently, more balanced and accurate.

${ }^{29}$ T. H. Jackson and A. T. Kronman, 'Secured financing and priorities among creditors' (1979) 88 Yale Law Journal, 1143; G. McCormack 'Reforming the law of security interests: national and international perspectives' (2003) Singapore Journal of Legal Studies 1 at 5; J. Armour, 'The law and economics debate about secured lending: lessons for European law making?' in The future of secured lending in Europe, eds. Eidenmüller - Kieninger, European Company and Financial Law Review, Special Volume 2 (2008) 3. See also the empirical works of: S. A. Davydenko and J. R. Franks, 'Do bankruptcy codes matter? A study of defaults in France, Germany, and the U.K.' (2008) 63 Journal Of Finance 565 and R. Haselmann, K. Pistor and V. Vig, 'How law affects lending' (2010) 23 Review of Financial Studies, 549 (positive correlation between rules on collateral and lending, while bankruptcy variables - including the variable 'secured creditors first' - have a lower relevance). The same philosophy is followed by the 'doing business' report developed by the World Bank: < http://www.doingbusiness.org/data/exploretopics/getting-credit\#close>

30 Non-sophisticated and involuntary creditors are commonly labelled 'non-adjusting creditors', while sophisticated creditors are defined 'adjusting creditors', since they can 'adjust' their market and contractual conditions. See: L. A. Bebchuk and J. M. Fried, 'The uneasy case for the priority of secured claims in bankruptcy' (1996) 105 Yale Law Journal 857, at 885 - 887 and T. Guzman, International Bankruptcy: In Defense of Universalism' (1999 - 2000) 98 Mich. L. Rev 2177.

31 See: A. Schwartz, 'Security interests and bankruptcy priorities: a review of current theories' (1981) 10 Journal of Legal Studies 1; L. Lo Pucki, 'The unsecured creditor's bargain' (1994) 80 Virginia Law Review, 1886; Bebchuk and Fried, op. cit., n. 30. 
This is the version of the article accepted for publication in the Journal of Law and Society that will be published by Wiley: http://onlinelibrary.wiley.com/journal/10.1111/(ISSN)1467-6478/issues

Accepted version downloaded from SOAS Research Online: http://eprints.soas.ac.uk/23221/

\section{THE MYTH OF INSOLVENCY LAW NEUTRALITY}

\section{Creditors' equal treatment versus statutory priorities}

One of the main goals of insolvency proceedings is addressing collective action problems faced by creditors when their debtors become insolvent. First of all, in order to prevent creditors from individually seizing their debtors' assets, a widespread strategy is providing a general stay of individual creditors' claims. Secondly, in order to avoid the risk that creditors reject a restructuring plans hoping to be paid in full if the plan succeeds (hold-out problem), rules on restructuring proceedings require that rescue plans are binding for all creditors when they are approved by a majority of creditors. According to a widespread view, insolvency rules should exclusively aim at facilitating the efficient liquidation of a debtor's assets or the most valueenhancing restructuring plan, to the advantage of all creditors, without altering pre-insolvency entitlements deriving from private bargains, such as pledges, mortgages and other guarantees. ${ }^{32} \mathrm{It}$ goes without saying that, in this conceptual framework, assets' distribution should follow the principle of par condicio creditorum, or pari passu, according to which secured creditors rank in priority to unsecured creditors and all unsecured creditors rank equally.

As a matter of facts, however, insolvency regimes are never neutral for the distribution of a debtor's estate to creditors and other stakeholders. Without a statutory stay of creditors' claims, for instance, creditors would seize the debtor's estate on a 'first come - first served basis', which would replicate a Hobbesian state of nature, where men are wolves for other men and the strongest prevails. ${ }^{33}$ In the business world, the most sophisticated and best-informed creditors would prevail over the less sophisticated, and probably less affluent, creditors. A statutory stay, however, respects pre-insolvency creditors' entitlements, such as privately negotiated guarantees. By contrast, statutory priorities any other rules altering pre-insolvency entitlements have a more pronounced distributive impact. ${ }^{34}$ In this regard, it is worth remembering that rules on creditors' ranking and priorities vary greatly from country to country, reflecting political options for the preferred equilibrium between classes of creditors $^{35}$, as well as domestic legal concepts, so that any classification is likely to be incomplete. ${ }^{36}$ Priorities, for instance, may be shaped in the form of privileges over proceedings deriving from the sale of specific debtor assets; such privileges could be characterised either as rights in rem, such as liens in common law jurisdictions, or as statutory alterations of creditors' ranking with regard to certain assets. ${ }^{37}$ Regardless of specific national classifications and rules, what matters for the purposes of this study is classifying statutory priorities according to their impact on other creditors' claims; we should, therefore, distinguish between: (a) statutory priorities that treat certain unsecured creditors preferentially to other unsecured creditors, while secured creditors take a higher priority to all unsecured creditors (hereinafter: 'simple priorities'); (b) statutory priorities that treat certain unsecured creditors preferentially to all other creditors' claims, including secured claims (hereinafter: 'superpriorities').

32 T. H. Jackson, The Logic and Limits of Bankruptcy Law (1986) $21-25$.

${ }^{33}$ T. Hobbes, De Cive (1642); $1^{\text {st }}$ English edition: Philosophicall rudiments concerning government and society (1651); see the Dedicatory Epistle to the Earle of Devonshire at 1: 'To speak impartially, both sayings are very true; That Man to Man is a kind of God; and that Man to Man is an arrant Wolfe'.

${ }^{34}$ Garrido, op. cit. (1995), n. 2, p. 31. Priorities follow local values and policy options, but do not necessarily protect local creditors only, as foreign creditors can also make use of these priorities: Pottow op. cit., n. 2, p. 1911.

${ }^{35}$ F. M. Mucciarelli, 'Not just efficiency: insolvency law in the EU and its political dimension' (2013) 14 European Business Organization Law Review 175.

${ }^{36}$ Garrido, op. cit. (1995), n. 2.

${ }^{37}$ With regard to systems deriving from the French code civil, see: Garrido, op. cit. (1995), n. 2; for Germany see Piekenbrock, op. cit., n. 2, pp. 87 - 93 and C. Paulus, 'The Wonderful Wolrd of Privileges - The Par Condicio Creditorum vs. Closeout-Netting’ (2014) European Company and Financial Law Review 531. 
Both simple priorities and super-priorities alter, albeit to different extents, the economic relations among creditors to the advantage of the preferred claims. Since an insolvent debtor's estate is likely to be not sufficient for satisfying all creditors' claims, statutory priorities, in practice, transfer value from other creditors to the prioritised class of creditors. While simple priorities just shift the economic burden of a debtor's insolvency from one class of unsecured creditors to another ${ }^{38}$, super-priorities also disregard privately negotiated guarantees to the advantage of certain categories of creditors. It is interesting to note that such rules produce redistributive effects among social actors by simply altering privately negotiated entitlements between a debtor and his or her stakeholders, instead of through tax-paid mechanisms. Needless to say that statutory priorities create tensions between prioritised and non-prioritised creditors. In this regard, we can borrow the words of the Cork Report, claiming that priorities should be 'justified by reference to principles of fairness and equity which would be likely to command general public acceptance. ${ }^{39}$

\section{Strategies for protecting employees}

When a firm enters into insolvent liquidation, employees lose the financial resources aimed at supporting them and their families, unless social security mechanisms exist that sufficiently support their needs until they find another job. Employees are in a particularly vulnerable position since their investment is firm-specific and undiversified. ${ }^{40}$ Employers, therefore, could exploit their position and behave opportunistically at workers' expense. Additionally, when the insolvent employer is a company, limited liability protects shareholders' private assets from creditors' claims, including employees' claims. Limited liability, therefore, exacerbates the risk of employers' opportunism ${ }^{41}$ and, indeed, not paying due wages and contributions in the vicinity of insolvency should certainly be added to the list of such opportunistic behaviours. Bearing this in mind, it is clear that employee priorities related to due wages and contributions are strategies for addressing the risk that employers use their insolvency as a shield for avoiding labour obligations.

\footnotetext{
${ }^{38}$ Garrido, op. cit. (1998), n. 2, pp. $32-36$.

39 Report of the Review Committee on Insolvency Law and Practice ('Cork Report'), Cmnd. 8558 (1982), at 1398.

${ }^{40}$ See: H. Hansmann, 'When does worker ownership work? ESOPs, law firms, codetermination, and economic democracy' (1990) 99 Yale Law Journal, 1749, at 1764 - 1765; O. Williamson, The economic institutions of capitalism (1985) 250 - 262; Hansmann, The ownership of enterprise (1996) 26: 'with time it may become increasingly costly, both professionally and personally, [for a worker] to change employers', with the consequence that 'her present employer is in a position to act opportunistically toward her in setting wages or other terms of employment, compensating her only well enough to prevent her from leaving and thereby, in effect, appropriating the value of the job-specific investments, both professional and personal, that she has made'; Williamson, 'The theory of the firm as governance structure: from choice to contract' (2002) 16 Journal of Economic Perspectives, 171, at 185: 'workers who acquire firmspecific skills will lose value if prematurely terminated (and firms will incur added training costs if such employees quit)' and the risk of moral hazards on the employers' side 'will result in demands by workers for a hazard premium, and recurrent contractual impasses, by reason of conflict, will result in inefficiency'; Roy Goode, Principles of corporate insolvency law (2011) $235-240$.

${ }^{41}$ E. Tucker, 'Shareholder and director liability for unpaid workers' wages in Canada: from condition of granting limited liability to exceptional remedy' (2008) 26 Law and History Review 58. In general, on the role of limited liability: Bebchuk and Fried, op. cit., n. 30, p. 899; J. Armour, G. Hertig and H. Kanda, 'Transactions with creditors, in The anatomy of corporate law, eds. Kraakman, Armour, Davies, Enriques, Hansmann, Hertig, Hopt, Kanda (2009 2nd edn) 116 - 117; S. Blankenburg, D. Plesch and F. Wilkinson, 'Limited liability and the modern corporation in theory and in practice' (2010) 34 Cambridge Journal of Economics 821, at 831.
} 
In continental Europe, employee priorities were probably firstly introduced by a reform of Tuscany insolvency law in $1713^{42}$, but the most famous version was in the French Civil Code of 1804, which codified previous French customary law that was aimed at protecting domestic workers. ${ }^{43}$ In an era when a fully-fledged social security was not developed, employee priority was mainly justified as a form of workers' social protection. During the $20^{\text {th }}$ Century, the International Labour Organisation codified the necessity of having such priorities in place. In 1949 the ILO convention on protection of wages stated that in the event of the bankruptcy or judicial liquidation of an undertaking, the workers employed therein shall be treated as privileged creditors either as regards wages due to them for service rendered during such a period prior to the bankruptcy or judicial liquidation as may be prescribed by national laws or regulations, or as regards wages up to a prescribed amount as may be determined by national laws or regulations. ${ }^{44}$ Each state should establish the 'relative priority' of those claims in relation to other creditors, giving regard to specific domestic circumstances and, obviously, to domestic welfare state infrastructures. This convention was adopted in an era where progressive and 'Keynesian' ideas were functional to post-world war II reconstruction and were, therefore, shared values at international level.

In 1992, however, the same organisation approved a further convention on labour protection ${ }^{45}$, which watered down the original provisions. Indeed, according to the new convention, workers' claims should be paid before other unsecured creditors, while secured creditors are not mentioned $^{46}$; furthermore, employee priority could be reduced or abolished 'where workers' claims are protected by a guarantee institution'. ${ }^{47}$ This innovation was the signal that the cultural and economic climate was changing - or had already changed - and that the interests of sophisticated secured lenders had gained relevance in the policy discourse. Indeed, a few years later, the Principles and Guidelines for Effective Insolvency and Creditor Rights System, issued in 2001 by the World Bank, gave more weight to the interests of business and bank and to the aim of protecting secured lenders. The Principles, in particular, stressed that '[a]ny priority placed ahead of the secured party represents a substantial cost, which is generally transferred back to borrowers in the form of higher interest rates and transaction costs. Often the public policy represented by the priority (say, benefiting workers) receives a minor and occasional benefit at a substantial cost to the entire commercial system. Such priorities should be eliminated, reduced, and, where public policy concerns are compelling, addressed by other legal reforms that do not compromise the system for secured lending'. ${ }^{48}$ In other words, only if pressed by 'compelling political concerns' to protect workers, politicians should intervene preferably by not altering preexisting entitlements deriving from private bargains between a debtor and his or her creditors.

42 Riforma degli Statuti di Mercanzia, issued motu proprio by the Grand Duke of Tuscany Cosimo $3^{\mathrm{d}}$ on April 11th 1713; see: Garrido, op. cit. (1998), n. 2, p. 22, footnote 51.

${ }^{43}$ French Civil Code (Code Civil des Français), original version issued on March $21^{\text {st }} 1804$ (usually called 'Code Napoleon'), article 2101 and article 2104. See Garrido, op. cit. (1998), n. 2, p. 35, and A. Bronstein, 'The protection of workers' claims in the event of the insolvency of their employer' (1987) 126 International Labour Review 715, at 718 720.

${ }_{44}$ Protection of Wages Convention, 1949 (No. 95) adopted $1^{\text {st }}$ July 1949, entered into force $24^{\text {th }}$ September 1952, article 11.

45 Protection of Workers' Claims (Employer's Insolvency) Convention, 1992 (No. 173) - adopted 23 June 1992, entered into force $8^{\text {th }}$ June 1995.

46 Protection of Workers' Claims (Employer's Insolvency) Convention, 1992, article 5.

${ }^{47}$ Protection of Workers' Claims (Employer's Insolvency) Convention, 1992, article 8.

48 World Bank Principles 2001, paragraph 58. See also paragraph 147: 'There is an observable tendency to increase the categories of debts enjoying such priority, for example by giving this status to each new form of tax or duty or each additional employee entitlement. Indeed, in countries with a strong tradition of worker protection there is sometimes an acute tension between the provision of safeguards for employees against the consequences of their employers' insolvency and the need of the bankruptcy trustee to keep the business viable and, if possible, restore it to profitability, which may involve a sharp reduction in the workforce.' 
This strategy clearly advantages sophisticated creditors, such as banks or large corporations, which have sufficient market power to require guarantees from their debtors. In a similar vein, the UNCITRAL legislative guide to cross border insolvencies, issued in 2004, emphasized that '[s]ome priorities are based on social concerns that may be addressed more readily by law other than the insolvency law, such as social welfare legislation, than by designing an insolvency law to achieve social objectives that are only indirectly related to questions of debt and insolvency. Providing a priority in the insolvency law may at best afford an incomplete and inadequate remedy for the social problem, while at the same time rendering insolvency proceedings less effective'. ${ }^{49}$ The idea behind this suggestion is that employee priorities and social security schemes are like communicating vessels, so that if a social security scheme is sufficiently broad, employees can recover the full amount of due wages and contributions and priorities are not necessary or less important.

In the European Union, a preference for social security mechanisms can probably be read between the lines of the Directive on Employees' Protection ${ }^{50}$, according to which Member States should put in place mechanisms that guarantee the payment of employees' outstanding claims relating to their employment, by establishing a 'guarantee institution' for securing 'payment of employees' outstanding claims resulting from contracts of employment or employment relationships'. ${ }^{51}$ Member States can exclude certain employees' claims from social guarantee's protection 'by virtue of the existence of other forms of guarantee if it established that these offer [...] a degree of protection equivalent to that resulting from this directive'. ${ }^{52}$ What is extremely interesting is that the Directive requires a factual and empirical comparison on whether a certain institutional setting is as effective as the mandatory 'guarantee institution'. The English regime is a telling example for alternative protections. The National Insurance Fund, protects employees' claims for due wages, with the exception of seamen's claims that are only covered by maritime lien. This is a guarantee created by operation of law over a ship and its cargo $^{53}$, granting seamen a priority over other creditors. The question arises as to whether these two strategies (social security v. statutory priority) produce equivalent effects for employees. In this regard, the European Commission stressed that this lien 'may not always offer a degree of protection equivalent to that of the National Insurance Fund'. ${ }^{54}$ Implicitly, the Commission argues that employee priorities are not as effective as social security schemes, and that Member States cannot replace the guarantee institution foreseen by the Directive on Employees' Protection through insolvency priorities. It is worth mentioning, however, that the Insolvency Regulation Recast of 2015 clearly stresses that different employee priorities across Member States are to be respected and that the next review of the regulation should identify further measures in order to 'improve preferential rights of employees at European level'. 55

49 UNCITRAL legislative guide 2004, section V, paragraph 68.

${ }^{50}$ Council Directive 80/987/EEC on the approximation of the laws of Member States relating to the protection of employees in the event of the insolvency of their employer [1980] OJ L 283/23. This directive was amended several times and eventually codified by Directive 2008/94 of the European Parliament and the Council [2008] L 283/36 (Directive on Employees' Protection).

51 Directive on Employees' Protection, article 1(1).

52 Directive on Employees' Protection, article 1(2).

53 International Convention on Maritime Liens and Mortgages, 1993, articles 4 and 5.

54 Report from the Commission to the European Parliament and the Council on the implementation and application of certain provisions of Directive 2008/94/EC on the protection of employees in the event of the insolvency of their employer, 28.2.2011, COM (2011) 84 Final, 3.

55 Regulation (EU) 2015/848 of the European Parliament and of the Council, on insolvency proceedings (recast) [2005] L141/19, recital 22. 
This is the version of the article accepted for publication in the Journal of Law and Society that will be published by Wiley: http://onlinelibrary.wiley.com/journal/10.1111/(ISSN)1467-6478/issues

Accepted version downloaded from SOAS Research Online: http://eprints.soas.ac.uk/23221/

\section{EMPLOYEE STATUTORY PRIORITIES IN FRANCE, GERMANY AND THE UNITED KINGDOM}

In the next section, employee priorities and social security mechanisms in France, Germany and the United Kingdom will be compared and contrasted. These countries share a common element, namely the implementation of the Directive on Employees' Protection. Nevertheless, rules on employees' ranking and social security schemes are combined in different ways, according to own domestic political and economic agenda.

\section{France}

According to the French regime, when an employer enters into an insolvency proceeding, all claims deriving from labour contracts are protected by a super-priority that curbs secured creditors' claims. ${ }^{56}$ Employees' super-priority has a broad scope, as it protects any employees' claims against their employers, including claims for paid leave. Such priority is capped at a monthly threshold of twice the amount used to calculate social and pension contributions, which can be increased and updated through a government regulation. ${ }^{57}$ Since the monthly amount for calculating social pensions in 2015 was $€ 3,170,{ }^{58}$ the statutory floor for employees' super-priority was $€ 6,340$. Employees' claims exceeding the monthly amount of the super-priority are entitled to a forth-rank privilèges généraux (a 'general privilege') on movable assets ${ }^{59}$ and a second-rank general privilege on immovable assets ${ }^{60}$ of their insolvent debtor. It is worth remembering that in France, like in other southern-European countries ${ }^{61}$, creditors' priorities have proliferated over recent decades and, in some cases, they have probably reached a saturation point beyond which preference creditors are scarcely protected or not protected at all. ${ }^{62}$ By introducing a superpriority, therefore, the French legislator tried to effectively protect employees, since simple priorities are likely not to be effective.

Besides these priorities, employees are also protected through an insurance mechanism based upon employers' contributions. ${ }^{63}$ In particular, all employers should insure the payment of all due salaries, including pension and insurance payments. This insurance mechanism is implemented through a special entity, created for that specific purpose by the national employer organisations, in agreement with the labour minister. ${ }^{64}$ The insurance fund protects any contracts of employment, including part-time contracts, fixed-term and temporary contracts, and guarantees any due payment without time limitation, up to a maximum amount which is updated every year (in 2015 the amount was $€ 76,080)$. When this insurance fund indemnifies employees, it is subrogated to employees' rights and is, therefore, entitled to super-priority vis-à-vis other creditors. The statutory priority, therefore, is a crucial element of this complex mechanism for protecting employees, for it allows the insurance fund (and indirectly its contributors: the employers as a

\footnotetext{
${ }^{56}$ Code de commerce, article L625-7 (originally in article 128 of the Loi 85-98 25 January 1985 on the redressement et à la liquidation judiciaires des entreprises and was transferred in article L6211-130 of the Code de commerce by the Loi 94-475, 10 June 1994, art. 92) referring to Code du Travail, article L143-10; this rule was originally introduced by Décret 731046, 15 $5^{\text {th }}$ November 1973 and since 2008 is embodied in Code du travail, article L3253-2.

${ }^{57}$ Code du travail, article L3253-2.

${ }^{58}$ Ministre des affaires sociales, de la santé et des droits des femmes - ministre de l'agriculture, de l'agroalimentaire et de la forêt - secrétaire d'Etat chargé du budget: Arrêté du 26 novembre 2014 portant fixation du plafond de la sécurité sociale pour 2015.

${ }^{59}$ Code civil, article 2331.

${ }^{60}$ Code civil, article 2375 (formerly in article 2104).

${ }^{61}$ Garrido, op. cit. (1995), n. 2, pp. $39-40$.

62 Garrido, op. cit. (1995), n. 2, p. 36.

63 This insurance mechanism was also created in 1973: Loi 73/1194, as amended. See now Code de travail, article L143-11-1.

${ }^{64}$ Code de travail, article L143-11-4 (Association pour la Gestion du régime d'assurance des créances des Salaires).
} 
This is the version of the article accepted for publication in the Journal of Law and Society that will be published by Wiley: http://onlinelibrary.wiley.com/journal/10.1111/(ISSN)1467-6478/issues

Accepted version downloaded from SOAS Research Online: http://eprints.soas.ac.uk/23221/

class) to recover what it paid for protecting employees' claims. The ultimate burden of this mechanism is hence placed upon other unsecured creditors' shoulders.

\section{Germany}

Germany has a reputation for strong social security mechanisms and worker protections, and is considered a typical example of coordinated market economies. Bearing this in mind, we can predict that German employees should be entitled to both a statutory priority for claims related to due wages and a strong social security, similarly to France. Nevertheless, the German Insolvency Act 1994, which entered into force in $1999^{65}$, abolished all creditor priorities, including priorities protecting employee claims for due wages, with the sole exceptions of a limited list of statutory liens ${ }^{66}$ and few other cases. ${ }^{67}$ The lack of employee priority is compensated by a social fund collectively financed by German employers. ${ }^{68}$ The policy goal of the German insolvency regime is to canalise employees' protections into just one strategy that socialises costs among the employers as a class. This social fund covers outstanding employees' claims related to a period of three months prior to the decision to open an insolvency proceeding, including wages, holiday pay, bonuses and pension contributions (Insolven zgeld). This fund protects any employees with outstanding pay claims, including part-time employees, employees with fixed-term or temporary contracts, regardless of whether they are also protected by statutory unemployment schemes. In 2004, the maximum amount of Insolvenageld was capped at the level of the monthly unemployment scheme payment. ${ }^{69}$ After a payment, the social fund is subrogated to employees' position vis-à-vis the employer. Therefore, the social fund does not enjoy any priorities and can only partially recover what it paid to employees.

A retrospective analysis, however, reveals that former insolvency rules of West Germany (Konkursordnung) $^{70}$ were amended in 1974 to introduce employee super-priority, similarly to the French regime. In particular, employees' claims for due wages over six months before their employers' insolvency ranked in priority to other creditors' claims, including secured creditors. ${ }^{71}$ In the same year, the West German Parliament introduced the guarantee mechanism protecting employee's claims for due wages. ${ }^{72}$ German employees' protection, therefore, followed the same path of France, just one year apart. In 1994, however, the Parliament of unified Germany, by reforming the insolvency law ${ }^{73}$, repealed all insolvency priorities, including employees' priority for due wages. This decision granted the pari passu principle to its full extent. ${ }^{74}$ Another consequence is that the liquidator can avoid any payments made a short time before filing for insolvency, including employees' wages paid within three months prior to the opening of the

\footnotetext{
${ }^{6}$ Insolvenzordnung (InsO), 5.10.1994, BGBl. I 2866, as amended.

${ }^{66}$ A. Piekenbrock, op. cit., n. 2, p. 63.

${ }^{67}$ In particular, set-off rights and rules on clos-out netting operate, in practice, as priorities or privileges; see: $\mathrm{C}$. Paulus, op. cit., n. 37 , pp. $531-553$.

68 Sozialgesetzbuch III 1997, \$165.

${ }^{69}$ Sozialgesetzbuch, 3d book [1997] BGBl, I/594, \$167.

${ }^{70}$ Konkursordnung, Deutsches Reichsgesetzblatt [1879] Nr. 10, 351 - 389. See: Piekenbrock op. cit., n. 2, p. 84.

${ }^{71}$ Konkursordnung \59(1) No 3-a, \60(1), and \61(1) No 1-a, introduced by the act 17th July 1974, BGBl I, 1481, article $2 \$ 1$ No $1-b$.

72 Arbeitsförderungsgesetz. (AFG) [1969] BGBl. I/582, \141a, as amended in 1974. The AFG was repealed in 1997 through the Sozialgesetzbuch, $3 d$ book.

73 Insolvenzordnung (InsO) [1994] BGB1 I/2866, entered into force on $1^{\text {st January }} 1999$.

${ }^{74}$ The only exception is related to employee contracts signed by the provisional administrator: $\operatorname{Ins} O \$ 55(2)$. For an overview see: M. Balz, 'Market conformity of insolvency proceedings: policy issues of the German insolvency law' (1997) 23 Brooklyn Journal of International Law 167.
} 
insolvency proceeding are avoidable, if the employees were aware of the insolvency. ${ }^{75}$ The official motivations for the Insolvency Act maintain that any creditor priorities are ultimately based upon arbitrary political decisions and, therefore, that these priorities are not logically justified. ${ }^{76}$ The 1994 reform also increased the likelihood of rescue proceedings, while under previous Konkursordnung an insolvent debtor' liquidation was the most likely outcome of insolvency. ${ }^{77}$

This issue was, however, intensively debated and the question arose as to whether this strategy would have harmed workers facing their employer's insolvency. In 1992, while debating the reform proposal, the main opposition party (SPD) agreed to repeal other creditor priorities, with the sole exception of employee priorities. ${ }^{78}$ Two years later, however, the SPD accepted the idea of also repealing employee priorities, arguing that in practice, in at least $3 / 4$ of cases such priorities are only on paper and in the residual $1 / 4$ of cases these priorities are effective only in few cases', and that other social security strategies, such as the Insolvenzausfallgeld, 'and other rules' (perhaps referring to the whole social security mechanisms) provide better protection for employees. ${ }^{79}$ Similarly, the official motivations for the Insolvency Act argued that the Insolven ageld was a sufficient protection for workers. The problem, however, was - and still is - that the Insolvenggeld only covers the payment of the last three months of due wages, while the former super-priority protected due wages of the last six months before insolvency. Nevertheless, the official motivation for the Insolvency Act argued that this gap of three months was of scarce practical relevance, without further explaining why this was the case. ${ }^{80}$

\section{United Kingdom}

In the United Kingdom, creditor priorities are almost unknown, and insolvency rules respect pre-insolvency entitlements and private bargains between a debtor and its creditors. In this regard, it is worth remembering that in 2002 the Crown preference for unpaid taxes was also abolished. ${ }^{81}$ The only exception is employees' preferential treatment regarding claims for due wages and contributions. Employees' claims, in particular, rank higher in priority than other unsecured creditors, while fixed secured creditors and insolvency practitioners' fees are prioritised over any other unsecured creditors, including employees. This protection covers any employees' due wages, including holiday remuneration and related rights ${ }^{82}$, for a period of four months prior to the starting day of the insolvency proceeding. ${ }^{83}$ This priority, however, is capped

\footnotetext{
$75 \mathrm{Ins} O \$ 130$.

${ }^{76}$ German Parliament [Deutscher Bundestag], 12 legislative period, Drucksache 12/2443, 15.04.92, at 90.

77 Balz, op. cit., n. 74.

${ }^{78}$ See the arguments of Mr Pick MP, German Parliament [Deutscher Bundestag] 12 legislative period, 94 Sitzung, 3.6.1992, at 7774 .

${ }^{79} \mathrm{Mr}$ Pick MP, German Parliament [Deutscher Bundestag] 12 legislative period, 222 Sitzung, 21.4.1994, at 19119.

${ }^{80}$ German Parliament [Deutscher Bundestag], 12 legislative period, Drucksache 12/2443, 15.04.92, at 90: 'Für die Arbeitnehmer sind keine sozialen Härten zu erwarten, da für die Lobnausfälle der letżten drei Monate vor der Eröffnung des Insolvenzverfahrens Konkursausfallgeld gezablt werden soll; ältere Rückstände sind selten von Bedeutung'.

81 Enterprise Act 2002 s. 251.

${ }^{82}$ Insolvency Act 1986, Schedule 6, Category 5. Such priority, however, dates back to the Preferential Payments in Bankruptcy Amendment Act 1897, s. 2. See now: Financial Services (Banking Reform) Act 2014 (Commencement No 7) Order 2014, SI 2014/3160. For Northern Ireland see: The Insolvency (Northern Ireland) Order 1989, s. 149 and Schedule 4, Category 5.

${ }^{83}$ Four different 'relevant dates' trigger this priority, according to the specific procedure: the date on which the company entered administration, the date on which a voluntary arrangement takes effect, the date of the appointment of a provisional liquidator, or the date of the winding-up order: Insolvency Act 1986, s. 387.
} 
at a maximum amount of $£ 800$, which has remained unaltered since $1976 .{ }^{84}$ In this respect, the Cork report of 1982, which set the conceptual framework for the Insolvency Act 1986, recommended an increase of this threshold, while the Trade Union Congress requested a complete abolition of any thresholds. ${ }^{85}$ Employees' residual claims above this threshold rank equal to other unsecured claims and, although a 'prescribed part' of debtors' estate should be made available for unsecured creditors ${ }^{86}$, the residual estate is likely not to be sufficient to satisfy employees' claims. The employee preferential treatment, therefore, only marginally alters preinsolvency entitlements. In 1976, however, the nominal value of $£ 800$ had a much higher purchasing power than today. A commonly used calculator of currencies' relative value ${ }^{87}$ shows that in 2015 the relative value of 1976's $£ 800$ ranges from $£ 4,820.00$ to $£ 11,520.00$, depending on the purposes for which this sum is to be used. The value of the 'historic standard of living', measuring the ability to purchase a bundle of 'basic' goods and services, is about $f, 5,200$ today. This means that all political parties that were holding the government office since 1976, by not adjusting this nominal value to inflation, have tacitly decided to continuously shrink the protection of employee priority to a quite low real value. Of course, there might be several justifications for this lack of adjustment, one of those could be that this mechanism for protecting employees is relatively unimportant, or that workers are mainly concerned with future unemployment rather than with past losses (which may be minimal since employees are paid monthly). As it may be, even if we assume that the total amount of unpaid due wages is relatively unimportant, the decrease in value of this priority is tantamount of a creeping abolition of this protection. ${ }^{88}$

In the present scenario, where employees' priorities have been reduced to a quite low amount, employees' protection is mainly based upon social security. In this regard, the Employment Rights Act 1996, which codified previous legislation and implemented the Directive on

84 This amount was originally increased to $£ 800$ by the Insolvency Act 1976, Schedule 1, Part 1 (amending Section 33(1)(b) and (c) of the Insolvency Act 1914) and then, following the enactment of the Insolvency Act 1986, it was confirmed by the Insolvency Proceedings (Monetary Limits) Order 1986, SI 1986/1996, s. 4.

${ }^{85}$ Report of the Review Committee on Insolvency Law and Practice ('Cork Report'), Cmnd. 8558 (1982), at 1433.

${ }^{86}$ Insolvency Act 1986, s. 176.

${ }^{87}$ I use the online calculator developed by L. H. Officer (University of Illinois at Chicago) and S. H. Williamson (Miami University): < https://www.measuringworth.com/ukcompare/ >.

${ }^{88} \mathrm{~A}$ further form of employee super-priority existed under the original version of the Transfer of Undertaking (Protection of Employees) Regulation 1981, SI 1981/1974 (TUPE 1981), which implemented the Business Transfer Directive (Council Directive $77 / 187 /$ EEC on the approximation of the laws of the Member States relating to the safeguarding of employees' rights in the event of transfers of undertakings, businesses or parts of businesses, OJ 1977 L61/26). TUPE Regulations 1981 s. 5(2) maintained that the transferee inherited all liabilities of the transferor vis-à-vis its employees. The House of Lord decision in the case Litster included in the scope of TUPE Regulations 1981 any unfair dismissals that took place before a transfer of undertaking, with the consequence that the transferee of an insolvent undertaking inherited all labour debts and that employees were put in a privileged position as compared to other creditors. See: Litster v Forth Dry Dock and Engeneering Co Ltd (1989) IRLR 161. The new Transfer of Undertakings (Protection of Employees) Regulations 2006 clarified that the regulation only applies to insolvency proceedings opened for restructuring the insolvent undertaking, and 'not with a view to the liquidation of the assets of the transferor.' SI 2006/246 (TUPE 2006), regulation 8(6). This reform implemented a provision of the new Business Transfer Directive (see: Council Directive 2001/23/EC OJ 2001 L82/16, article 5), which however leaves Member States the possibility of opting-out. See: S. Deakin and G. S. Morris, Labour Law (2012, 6 ${ }^{\text {th }}$ ed.) 588. This debate is far from being peculiar of the UK regime. In France, the transferee inherits all liabilities of the transferor, except when the latter has entered an insolvency procedure of sauvegarde, redressement judiciaire or liquidation judiciaire: Code de travail, article L1224-2. In Germany, on paper the transferee should inherit all liabilities of the transferor without exceptions ( $\$ 613$ a BGB), but, according to case law of the Federal Labour Court, when the transfer occurs after an insolvency procedure has been opened, the transferee does not inherit liabilities that arose before the filing for insolvency; see: Bundesarbeitsgericht, 20 th June 2002, 8 AZR 459/01, in ZIP (2003) 139. 
Employees' Protection, offers a security scheme for protecting workers. ${ }^{89}$ If an employer becomes insolvent, the National Insurance Fund, which is funded through contributions of both employee and employers, must pay debts owed to employees, including (if there was no unfair dismissal and the employer has given proper notice) arrears for a maximum of eight weeks at a rate of $£ 464$ a week, unused holiday pay, with a maximum of six weeks and up to a weekly limit of $f 464$, and a statutory redundancy payment. The Insolvency Service protects any employment contracts, excluding merchant seamen (who, as we have seen above, are supposed to be sufficiently protected by maritime liens). ${ }^{90}$ Furthermore, this protection does not cover masters or members of the crew of fishing vessels when their payment is a share of profits or gross earnings of the vessel. ${ }^{91}$ The National Insurance Fund is subrogated to the rights of employees and is entitled to the same preferential status within the limit of $f, 800$ per employees. ${ }^{92}$

Finally, in order to have a full picture of employees' protection mechanisms, it is necessary considering that the risk of being held liable for fraudulent trading or for wrongful trading, and the risk of disqualification, could deter directors from not paying due wages and contributions to employees. First of all, directors could be held liable towards the company when they intentionally defrauded creditors (fraudulent trading) ${ }^{93}$, for instance when they deliberately pay only some of their company's creditors, with the consequence that other creditors are not paid in full. ${ }^{44}$ Furthermore, directors risk being liable to contribute to their company's assets, when they did not 'took every step with a view to minimising the potential loss to the company's creditors' in a moment when insolvency was unavoidable (wrongful trading). ${ }^{95}$ In both cases, however, the liquidator should commence litigation and the insolvency assets support all costs, which makes such actions not frequent. ${ }^{96}$ Directors' disqualifications, by contrast, is financed through public funding and prove much more effective. ${ }^{97}$ Courts, in particular, can issue a disqualification order for 'unfitness' when they are satisfied that a director' conduct 'makes him unfit to be concerned in the management of a company'. ${ }^{98}$ A typical case of 'unfitness' occurs when directors of a nearly insolvent company only pay certain classes of creditors, disregarding other creditors' claims. ${ }^{99}$ Therefore, the risk of being disqualified might prevent directors from disregarding employee wages and contributions when insolvency approaches.

${ }^{89}$ Employment Rights Act 1996, s. 166 - 169.

${ }^{90}$ Employment Rights Act 1996, s. 199(4) and s. 199(5).

${ }^{91}$ Employment Rights Act 1996, s. 192(2).

${ }^{92}$ Employment Rights Act 1996, s. 167(3)(a). Interestingly, the Cork Report in 1982 recommended that the Secretary of State should not enjoy any preferential status and that he should be subrogated as an unsecured creditor, not as a preferred one. The reason was that 'the priority accorded to employees in an insolvency is a social measure, intended to alleviate special financial hardship, and that in modern times the cost of meeting such social needs ought properly to be borne by the community'.

${ }^{93}$ Insolvency Act 1986, S. 213.

94 Starglade Properties Ltd v Nash [2010] EWCA 1314.

${ }^{95}$ Insolvency Act 1986, S. 214.

${ }^{96}$ P. Davies and S. Worthington, Gower and Davies' Principles of Modern company Law (2012, 9 $9^{\text {th }}$ ed.) $236-237$.

${ }^{97}$ Company Directors Disqualification Act 1986.

${ }^{98}$ Company Directors Disqualification Act 1986, s. 6

99 Sevenoaks (Stationers) Retail [1991] Ch 164; Secretary of State for Trade and Industry v McTighe [1997] B.C.C. 224; Official Receiver v Barnes [2001] B.C.C. 578; Official Receiver v Roger Charles Gawn [2014] Ch. WL 1219446. Ironically, in most of these cases, directors neglected the Inland Revenue, which did not press for payment, and prefer paying other creditors, including workers. 
This is the version of the article accepted for publication in the Journal of Law and Society that will be published by Wiley: http://onlinelibrary.wiley.com/journal/10.1111/(ISSN)1467-6478/issues

Accepted version downloaded from SOAS Research Online: http://eprints.soas.ac.uk/23221/

\section{MAKING SENSE OF DIFFERENT EMPLOYMENT PROTECTION STRATEGIES}

\section{Complementarity between employee statutory priority and insurance scheme}

The comparative analysis undertaken so far reveals that France, Germany and the U.K. provide for social security schemes that protect employees' claims for due wages and contributions. Their strategies, by contrast, diverge significantly regarding the question whether employees also should be protected through insolvency priorities. France combines an employee 'super-priority' (within a high threshold) and a security scheme. This is, therefore, a case of 'complementarity as reinforcement', where two institutional settings (social security and statutory priority) aim at attaining the same goal and mutually reinforce each other. In Germany, employees do not enjoy any priorities and are only protected by a social security scheme based upon employers' contributions. Therefore, the interplay between insolvency rule and social security scheme is clearly a case of 'complementarity as compensation', where the social security scheme compensates the lack of employee priorities. ${ }^{100}$ The English regime combines a priority and a social security scheme, but the employee priority is not as effective as their French counterparts: employees' claims are only prioritised over unsecured claims and floating charges, and their priority is capped at a low amount $(£ 800)$. The picture is further complicated by the fact that directors face the risk of a disqualification order when they treat one class of creditors preferentially to the disadvantage of other creditors. The interplay between insolvency rules, social security schemes and disqualification rules is to be classified as 'complementarity as compensation', where certain institutional settings (the social security and the disqualification rules) compensate other institutions' weaknesses (employee priority).

The historical analysis conducted hitherto has revealed a much more complex scenario. In particular, France's policy has remained unaltered since its introduction in 1973. The most interesting developments, however, occurred in the U.K. and in Germany. In the former country, the nominal value of the priority has never been adjusted to inflation and currency devaluations, so that its real value in 1976 was roughly six times as big as it is today. Originally, therefore, the interplay between employee priorities and social securities was to be classified a weak version of 'complementarity as reinforcement'. In Germany, between 1974 and 1999 a super-priority was combined with a guarantee fund, and, therefore, its regime was identical to the French employees' protection regime. ${ }^{101}$

This longitudinal analysis leads to two interesting remarks. First, in the U.K. and Germany, albeit along different paths, the institutional complementarity between the ranking of employees' claims and social security schemes has changed. As we have seen, in both regimes these institutional settings were originally connected in the guise of a 'complementarity as reinforcement', while at the turn of the twenty-first Century the social security schemes compensated deficiencies as to labour priorities. Such evolution indicates that institution building (such as the decision of repealing employee priority or not adjusting the nominal value of its cap)

100 This comparative analysis is briefly summarised in the following table:

\begin{tabular}{|l|l|l|l|}
\hline Country & Employee priority & Social security & Complementarity \\
\hline France & Yes (Super-priority) & Yes & 'Reinforcement' \\
\hline Germany & No & Yes & 'Compensation' \\
\hline U.K. & Yes (Simple priority with low cap) & Yes & 'Compensation' \\
\hline
\end{tabular}

101 The institutional settings in these countries in 1976 (date of the U.K. insolvency reform) is summarised in the following table:

\begin{tabular}{|l|l|l|l|}
\hline Country & Employee priority & Social security & Complementarity \\
\hline France & Yes (Super priority) & Yes & 'Reinforcement' \\
\hline Germany & Yes (Super priority) & Yes & 'Reinforcement' \\
\hline U.K. & Yes (Simple priority with high cap) & Yes & 'Weak reinforcement' \\
\hline
\end{tabular}


may be independent from previous institutional complementarities, and may derive from specific political motivations and dynamics. ${ }^{102}$

The second remark is that the 'varieties of capitalism' theory and the 'legal origin' hypothesis can only partially explain the interplay between a priority system and social security schemes. Notably, today's English and French regimes are coherent with their standard classifications, while Germany is not. The English regime, indeed, fits into its common classification as a liberal market economy' and into the 'broad conception whereby 'common law stands for the strategy of social control that seeks to support private markets outcomes ${ }^{103}$; the French regime, by altering free-market bargains to the employees' advantage, is coherent with its classification as 'coordinated market economy' and with the core tenet of civil law countries. Germany, by contrast, shows a quite puzzling regime: the decision taken in 1994 of abolishing creditor priorities is much more coherent with the ideal-type of liberal market economies rather than with a coordinated market economy, since its underlying philosophy is that free-market private bargains should not be altered; this was a quite drastic U-turn from previous policy options and German political elites seem to have imported into the German system a regulatory choice rooted in other legal and economic environments. ${ }^{104}$ If we turn our attention to the "70s, however, the classification of the English regime would have been much more controversial, while the German regime, being identical to the French one, was in line with the ideal-type of a coordinated market economy.

\section{The tendency towards labour 'commodification'}

Since employee priorities in France, Germany and the U.K. do not perfectly fit into the distinction between liberal and coordinated market economies, other explanatory tools should be developed in order to make sense of the interplay between employee priorities and social security schemes. To this aim, we can turn our attention to the fundamental relationship between labour and capital. In the last pages we have noted an increasing tendency to protect employees through insurance-based schemes, rather than through statutory priorities that alter pre-insolvency entitlements. This tendency is to be found in the official policy documents of the World Bank and the OECD over the last decades, as well as in British and German policy choices. This strategy maintains that there is no rational justification for altering the ranking of creditors to the advantage of any particular class of unsecured creditors, including employees, and that the policy goal of protecting employees is to be achieved without modifying free-market private bargains. This idea is based upon the implicit assumption that contracts between an undertaking and its employees are not different from contracts with other trade partners or suppliers, and that employees are akin to any other creditors.

This assumption has a precise legal foundation. In the world of legal concepts, indeed, entrepreneurs, employees and other contractual parties equally have legal personality and, therefore, are placed on the same footing under a legal standpoint. The concept of legal

102 W. Streeck, 'Explorations into the origins of non-liberal capitalism in Germany and Japan' in The origin of nonliberal capitalism, eds. Streeck and Yamamura (2001) 1. See also M. Höpner, 'What connect industrial relations and corporate governance? Explaining institutional complementarity' (2005) 3 Socio-Economic Review, 331, at 346, arguing for an increasing 'shareholder orientation' of German capitalism since the ' $90 \mathrm{~s}$.

${ }^{103}$ La Porta et al., op. cit., n. 14.

${ }^{104}$ On the effectivity of legal transplants of legal institutions, according to their connection to specific fragments of society, see G. Teubner, 'Legal Irritants: Good Faith in British Law or How Unifying Law Ends Up in New Differences' (1998) 61 Modern Law Rev. 11, at 17 - 19. 
personality paves the way for creating a market in which relation between an undertaking and its employees are identical to any other contractual relations with trade partners or suppliers, with the consequence that labour power is bought and sold like any other commodity. ${ }^{105}$ It would be wrong, however, to downplay the relevance of this ingenious legal construction as a mere ideological superstructure. Far from this, the formal equality between employers and employees, which derivers from the concept of legal personality, reflects the fact that in capitalist economies labour-power is to be treated as a commodity and labour itself becomes wage-labour. The concept of legal personality hides and politically neutralises the position of labour within the business and the intrinsic unequal position between these parties. ${ }^{106}$ In reality, however, labour relations are not like other relations between an undertaking and its trade partners or its suppliers, for the simple reason that employees are embedded in the business and in the production. Furthermore, the capacity to work cannot be separated from the worker as a human being, and 'cannot be shoved about, used indiscriminately, or even left unused, without affecting also the human individual who happens to be the bearer of this peculiar commodity', with the consequence that the 'commodity description of labor [...] is entirely fictitious'. ${ }^{107}$ This idea is clearly expressed in the declaration of Philadelphia on the aims and purposes of the International Labour Organisation, which maintains that 'labour is not a commodity'. ${ }^{108}$

These arguments allow us to understand the relevance of rules on prioritisation of employees' claims in insolvency proceedings. The common argument against employee priorities is that there is no logical justification for such preferential treatments, which are exclusively based upon political decisions. The implicit assumption is that there is no difference between employees' claims and any other creditors or trade partners' claims. In other words, this argument accepts as a reality the description of labour as a commodity, which the entrepreneur purchases like any other commodities; the equivalence between employees and other creditors leads to the conclusion that there is no logical justification for any preferential treatment. The entrepreneur is conceptually placed at the centre of a web of contractual relations, whereby any distinctions among different creditors blur and the specificity of labour in the business vanishes. A further consequence is that the sphere of the market and economy and the sphere of politics are conceptually separated and are constructed as mutually independent. ${ }^{109}$

By contrast, employee priorities are based on the assumption that, in reality, a profound difference exists between employees and other creditors of the same undertaking, and that labour is not like any other commodity that a company purchases from trade partners. Furthermore, labour priorities also bridge the conceptual divide between the 'economic' and the 'political' sphere. Therefore, rules on employee ranking in insolvency, and on insolvency priorities, cast light on profound tendencies of a country's political economy, much more than other statutory priorities that protect certain classes of unsecured creditors. The tendency that we have observed in Germany and England, although through different country-specific patterns, can be explained as a piece of a more general cultural shift that increasingly treats employees like any other creditors and labour like any other commodities that entrepreneurs purchase. This

${ }^{105}$ K. Marx, Das Kapital, Volume 1 (1863) ch. 6: 'labour-power can appear upon the market as a commodity, only if, and so far as, its possessor, the individual whose labour-power it is, offers it for sale, or sells it, as a commodity' and that employees and employers 'meet in the market, and deal with each other as on the basis of equal rights, with this difference alone, that one is buyer, the other seller; both, therefore, equal in the eyes of the law'.

106 P. Barcellona, I soggetti e le norme (1984) 119 - 123.

${ }^{107}$ K. Polanyi, The great transformation: the political and economic origins of our time (2001, $1^{\text {st }}$ ed. 1944) 76. See also J. F. Weeks, Economics of the 1\% (2014) 30.

${ }^{108}$ ILO, 26 $6^{\text {th }}$ session, $10^{\text {th }}$ May 1944, article 1 (a).

${ }^{109}$ See: Polanyi, op. cit., n. 106, p. 74: 'A self-regulating market demands nothing less than the institutional separation of society into an economic and political sphere. Such a dichotomy is, in effect, merely the restatement, from the point of view of society as a whole, of the existence of a self-regulating market.' 
This is the version of the article accepted for publication in the Journal of Law and Society that will be published by Wiley: http://onlinelibrary.wiley.com/journal/10.1111/(ISSN)1467-6478/issues

Accepted version downloaded from SOAS Research Online: http://eprints.soas.ac.uk/23221/

tendency also reveals the increasing centrality of entrepreneurs, as compared to labour, in legal and economic discourse.

\section{Are employee priorities and security schemes functional equivalents?}

Even accepting the critical analysis put forward hitherto, a pragmatic approach may induce scholars and policy makers to argue that a cumulative application of employee priority and social security schemes (namely a combination of these strategies in the guise of 'complementarity as reinforcement') is redundant. In this regard, the question arises as to whether, and under which conditions, a legal institution in a given jurisdiction is to be considered a functional equivalent to a different legal mechanism in another jurisdiction that pursues the same goals or protect the same social needs. ${ }^{110}$ Along this line of thinking, employee priorities and security schemes aim at satisfying the same social need and, therefore, they may be considered functional equivalent or functional substitutes; thus, we could argue that different national insolvency regimes are equivalent when they protect employees in one way or another. Under a policy standpoint, a possible consequence is that a cumulative application of both mechanisms is considered redundant. This was also the implicit assumption behind the recommendation of the World Bank Principles of 2001 and the UNCITRAL legislative guide of 2004, which stressed that the most adequate strategy for protecting employees or other weak stakeholders is through social security or insurance schemes.

This way of conducting a functional comparative analysis, however, does not consider how employee priorities and security schemes are connected to each other, and the impact of these connection on social actors involved in the insolvency of a company or an entrepreneur. ${ }^{111}$ In this regard, it is worth remembering that these rules govern the mutual relations among four classes of stakeholders: financial institutions (secured creditors), employees, other unsecured creditors and the insolvent employer. Their mutual relations also depend on how the priority system and the security scheme of a given jurisdiction are connected to each other. In the three countries considered in this study, the insurance scheme, after having paid employees' due wages and contribution, has the right to be subrogated in employees' claims on the debtor' estate and enjoys the same priority. ${ }^{12}$ Such subrogation also affects the recovery rate of the insurance scheme.

In France, therefore, where employees take priority over secured creditors, the security fund is likely to recover a significant portion of the amount paid, while unsecured creditors carry the main cost of employment protection. This institutional setting reflects a coalition between labour and employers, while unsecured creditors suffer a haircut; to a certain extent, banks and financial institutions are also likely to suffer a partial haircut up to the value limitation of employee super-

${ }^{110}$ See: K. Zweigert and R. Kötz, Comparative law (1998, 3d ed.) 37 - 41; R. Michaels, 'The functional method of comparative law' in Oxford Handbook of comparative law, eds. Reimann and Zimmermann (2006) 340. It can not be in the scope of this paper addressing the much debated issue of the merits and limits of a 'functional approach' to comparative law; on this debate see, with further reference Siems, op. cit., n. 14, pp. 25 - 28 and J. De Coninck, 'The Functional Method of Comparative Law: Quo Vadis?' (2010) 74 RabelsZ 318.

111 On the interplay of legal institutions and economic factors, shaping coalitions among social forces, see: R. V. Aguilera and G. Jackson 'The cross-national diversity of corporate governance: dimensions and determinants' (2003) 28 The Academy of Management Review 447 at 459.

${ }^{112}$ In other countries, however, the insurance scheme subrogated in the emplyees' rights does not receive the same priority of employees and is treated as a normal unsecured creditors (eg: Denmark, Sweden, Switzerland): Secunda, op. cit., n. 1, p. 919. 
priority, which depresses their returns. ${ }^{113}$ The same conclusions were valid for the German regime until 1999, while in today's German system, where no priority exists, the security fund suffers a haircut as it is reimbursed pro rata as unsecured creditor. In England, since employee priority is capped at a low amount, the National Insurance Fund is also likely to recover a small portion of the amount paid. The institutional settings of England and Germany, therefore, seem to reflect a coalition between financial institutions (secured creditors) and employees. ${ }^{114}$

This analysis reveals that different combinations of statutory priorities and insurance mechanisms produce different social and economic outcomes. Although insurance funds and statutory priorities protect the same social need, these institutional settings cannot be described as mere functional substitutes. When the insurance schemes is subrogated in employees' position and enjoys the same right and priority on the debtor' estate, it is not irrelevant for the overall balance of interests whether workers also enjoy a super-priority, a simple priority or no priority at all. Indeed, when employees are treated preferentially, the insurance scheme will be able to recover a larger amount of the employees' claims, which will contribute to its bargaining power and its long-term financial viability. ${ }^{115}$ This conclusion also has a significant policy implication, namely that when the insurance schemes has the right to be subrogated to employees' claims, a cumulative application of employee priorities and social security is not always redundant, mostly so when employees also take priority over secured creditors.

\section{CONCLUSIONS}

This paper comparatively describes employee priorities for due wages and contributions in three jurisdictions: France, England and Germany. These jurisdictions are representative of different production regimes or 'varieties of capitalism': England is the model of 'liberal market economies', whereas Germany and France are commonly classified as 'coordinated market economies'. Furthermore, these jurisdictions are emblematic of common law (England) and civil law countries (France and Germany); according to the legal origin hypothesis, this classification explains different level of financial development across different countries. This paper, in particular, has addressed the interplay of employees' priorities (if existing) with social security schemes aimed at protecting employees' interests in these jurisdictions.

Following the 'variety of capitalism' approach and the 'legal origin' hypothesis, we would expect that no priority should exist in England, whereas France and Germany should protect employees' through insolvency priorities. A comparative analysis has revealed a much more complex and faceted scenario. In particular, the German regime, by abolishing priorities in 1999 seems to be more in line with an ideal-type of 'liberal market economy', while the English regime and the French regime are more coherent with their standard classifications. Furthermore, if we turn our attention to the situation during the Seventies we note that in England the real value of the cap placed to employee priority was quite high and that in Germany employees also enjoyed a superpriority, similarly to the French system. This longitudinal picture, therefore, reveals a quite univocal result: that employment protection has been reduced over the last 40 years in England and in Germany, and is now entrusted only (or predominantly) to social security schemes.

\footnotetext{
${ }^{113}$ This is one of the reasons why France ranks at a lower position in the World Bank' 'doing business' report: $<$ http://www.doingbusiness.org/data/exploreeconomies/france/getting-credit/>

${ }^{114}$ Germany, in other words, revealed its profound nature of being a 'bank-based system': Aguilera and Jackson, op. cit., n. 110, p. 447. See also the 'doing business reports' for Germany (< $<$ http://www.doingbusiness.org/data/exploreeconomies/germany/getting-credit/ $>$ ) and the U.K. (< $<$ http://www.doingbusiness.org/data/exploreeconomies/united-kingdom/getting-credit/ $>$ )

${ }^{115}$ Secunda, op. cit., n. 1, p. 874.
} 
At a more general level, the classification of England as a pure liberal market economy can explain why secured creditors' preferential treatment has never been challenged. Nevertheless, this classification cannot fully explain why in the Seventies the British government decided to increase the cap of employee priorities to a high value, which altered their relations with other unsecured creditors. In the United Kingdom, therefore, different social and political forces can succeed in imposing their interests and views and can alter established equilibriums, although these forces have not managed to alter the economic and political predominance of the financial system, which requires secured creditors' absolute priority to be respected. The case of Germany is even more complex and curious: in 1994, German political elites decided to completely abolish any statutory priorities, including employee priorities; the consequence being that the German regime of today, at least in this regard, by fully respecting pre-insolvency entitlements, is much more in line with the ideal-type of a 'liberal' market economy.

In order to make sense of this development, we have turned our attention to the relation between labour and capital. When employees are not prioritised, their claims are treated like any other trade partners' claims and, consequently, labour is conceived like any other commodities that are purchased by a company on a market. By contrast, if employees enjoy a statutory priority, politics treats workers differently from other creditors. Therefore, rules on employees' ranking shed light on profound tendencies of a country's political economy, which can probably only be explained as an element of much broader and long-term historical developments. Finally, this paper takes issue with the idea that employee priorities and social security schemes are functional equivalent. This study has shown that it is not irrelevant whether employees, besides social security protection, also enjoy a priority or not. These mechanisms are indeed strictly intertwined, because social security schemes in France, Germany and England are subrogated to employees' rights and, therefore, if employees rank in priority over other creditors (in the guise of either a super-priority or a simple priority), the insurance fund should also be treated preferentially, whereas if no employee priority exists, claims of the insurance fund towards the insolvent employer rank equal to other unsecured claims. Employees' priorities, therefore, reinforce the long-term financial viability of social security schemes, but, ironically, they also place the ultimate burden on other unsecured creditors' shoulders. In a system with a super-priority, such as France (or Germany until 1999), the insurance scheme can recover a significant portion of the total amount paid, while in systems without priorities (Germany) or with a priority capped at a low level (England) the social security scheme suffers a haircut like any unsecured creditors. Therefore, a mere description of these two mechanisms - statutory priority and social security scheme - as functional substitute does not give proper account of their legal interconnections and their reciprocal embeddedness. 